\title{
Morphosyntactic Properties of Chibchan Verbal Person Marking ${ }^{1}$ \\ Matthias Pache \\ Leiden University
}

In typological terms, Chibchan is among the more heterogeneous language families in the Americas. This language family may therefore be considered as a relevant source of information on typological diversity and change. Chibchan languages are spoken in an area that extends from Honduras in the west to Venezuela in the east (see Map 1). In this language family, Adelaar (2007) has noted an uneven distribution of morphological complexity in terms of the number of categories encoded by bound elements. As a rule of thumb, the morphological complexity of Chibchan languages spoken in the eastern parts of the distribution area is relatively high. In contrast, several Chibchan languages spoken in Central America (Panama, Costa Rica) are somewhat less complex, morphologically speaking, that is, they tend to make use of more analytic constructions. One core area of typological diversity within Chibchan is verbal person marking, with synthetic verbal person marking attested for instance in Muisca and Barí (eastern part of the distribution area), and more analytic strategies attested for instance in Cabécar and Guaymí (central-western part of the distribution area) (see (1) and (2)). ${ }^{2}$

Barí

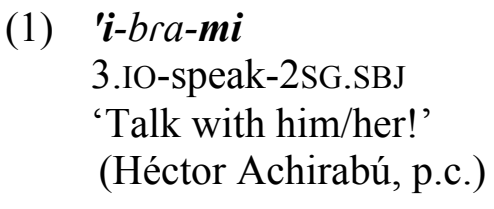

Cabécar

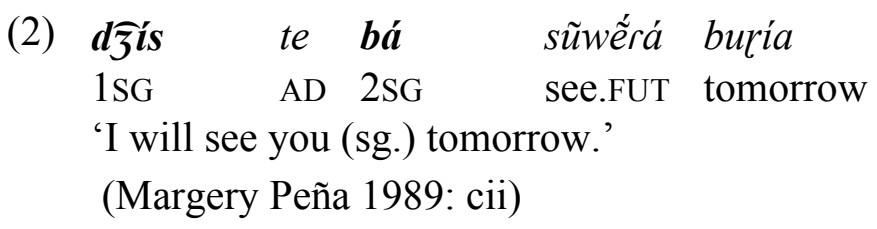

\footnotetext{
${ }^{1}$ The research leading to this paper has received funding from the European Research Council under the European Union's Seventh Framework Programme (FP7/2007-2013) / ERC Grant Agreement No. 295918. I am very grateful to Willem Adelaar, Natacha Chevrier, Rik van Gijn, Nicholas Ostler, Matthias Urban, Søren Wichmann, Fernando Zúñiga and an anonymous reviewer for their comments on an earlier version of this paper. I am also grateful to Héctor Achirabú from the community of Aruutatakae, Venezuela, who contributed to the present paper with an example from his language, Barí.

${ }^{2}$ Transcriptions are phonemic and use IPA, except for Barí and Muisca examples. Barí transcriptions are phonetic (fieldwork data). Muisca data are presented in the original spelling since there are only premodern sources for this language. Tone is indicated with an acute accent for high tone and with a grave accent for low tone. In the language examples, verbal person markers are in bold. The following abbreviations are used: $1=$ first person; $2=$ second person; $3=$ third person; $\mathrm{AD}=$ agent disambiguator; $\mathrm{ABS}=$ absolutive $; \mathrm{AUX}=$ auxiliary; $\mathrm{DAT}=$ dative $; \mathrm{DECL}=$ declarative; $\mathrm{DEM}=$ demonstrative $; \mathrm{ERG}=$ ergative; FUT = future; IO = indirect object; IPFV = imperfective; IRR $=$ irrealis; $\mathrm{L}=$ locative; $\mathrm{N}=$ non-; OBJ $=$ object $; \mathrm{PFV}=$ perfective; $\mathrm{PL}=$ plural; $\mathrm{PNCT}=$ punctual; poss $=$ possessive $;$ prs $=$ present; $\mathrm{PST}=$ past; $\mathrm{Q}=$ question marker; $\mathrm{SBJ}=$ subject; $\mathrm{SF}=$ stem formative; $\mathrm{SG}=$ singular; $\mathrm{STAT}=$ stative; $\mathrm{TNS}=$ tense.
} 
In Barí arguments are indexed on the predicate (1), while in Cabécar both subject and object person are indicated by unbound elements (2).

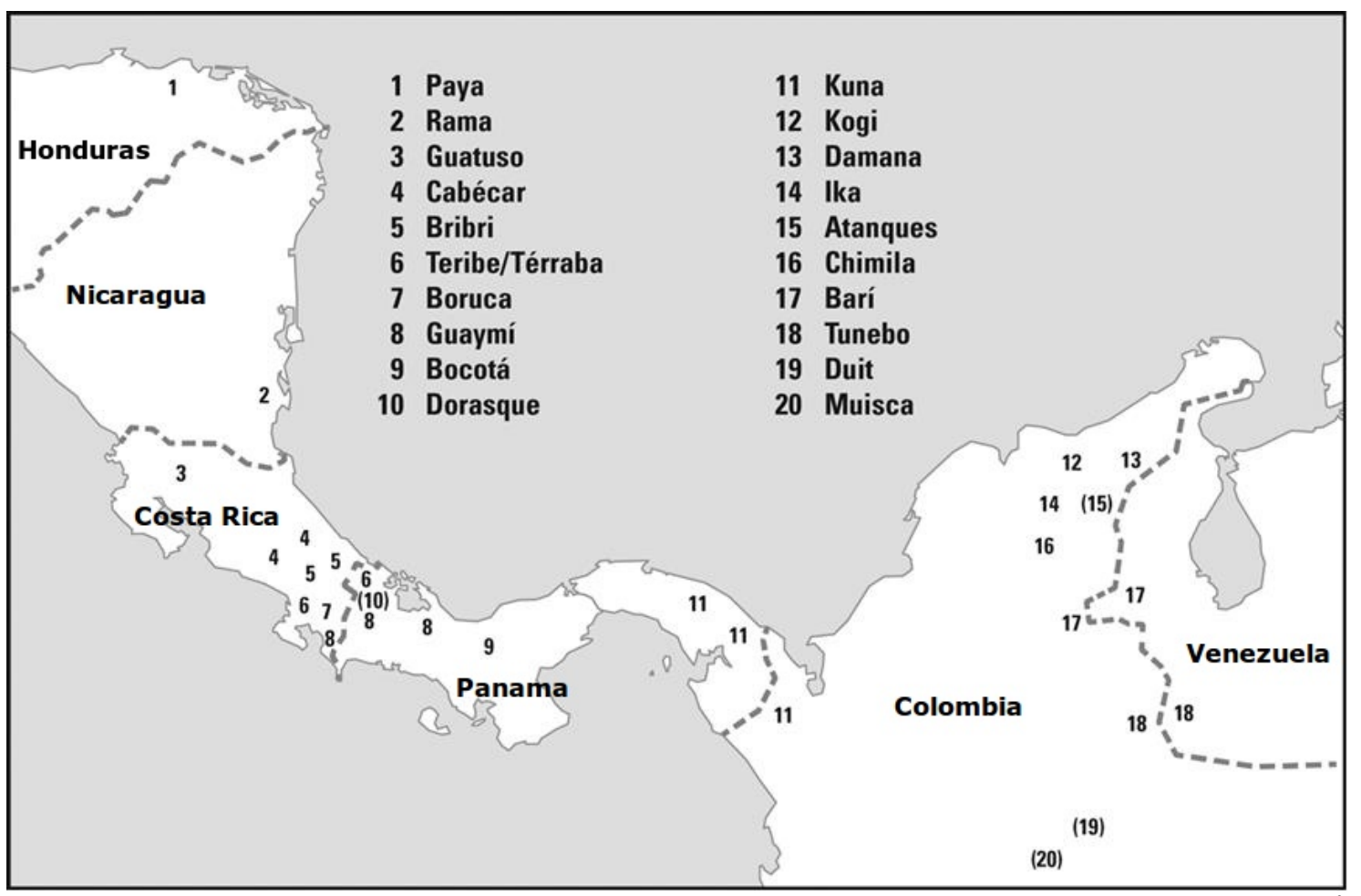

Map 1. Approximate distribution of Chibchan Languages (redrawn after Constenla Umaña 1993: 109) ${ }^{3}$

The present paper aims to shed more light on the morphosyntactic properties of Chibchan verbal person marking, both from a diachronic and a synchronic perspective. Section 1 gives a brief overview of verbal person marking patterns in Chibchan. In section 2, I will give some specific evidence for diachronic developments in different Chibchan languages. In section 3, it is argued that from a synchronic point of view, the morphological complexity of verbal person marking correlates with cognitive accessibility in some Chibchan languages.

\section{Chibchan Patterns of Verbal Person Marking}

Chibchan languages have different strategies of personal reference marking on verbs, namely bound and unbound elements. The present section will briefly present and discuss them. As indicated by van Gijn (this volume), the interpretation of elements as bound or unbound is not always an easy task. For the present paper, the interpretations given in the cited grammars were checked for that on the following criteria: elements that can appear on their own are always interpreted as unbound. Elements that occur in a fixed order are mostly interpreted as affixes. ${ }^{4}$ Clitics are a heterogeneous category (cf.

\footnotetext{
${ }^{3}$ Numbers in brackets refer to languages that are no longer spoken.

${ }^{4}$ Compare Haspelmath (2011) on these criteria and the difficulties to draw a clear line between syntax and morphology.
} 
e.g. van Gijn \& Zúñiga 2014), and sometimes difficult to tease apart from affixes in Chibchan. ${ }^{5}$

In Chibchan verbal person marking, we find prefixes ((3) and (5)), suffixes (4), a mix of both (6), or unbound forms (7). Examples (3) and (4) illustrate intransitive constructions.

\section{Muisca}

(3) $<$ i-na $>$

1SG.SBJ-go

'I go', 'I went'

(González de Pérez 1987: 123, cited in Adelaar \& Muysken 2004: 92)

In Muisca (3), the prefix $<\mathrm{i}->$ indicates $1^{\text {st }}$ person subject. ${ }^{6}$ In Chimila, suffixes are used for verbal person marking, for instance $-g^{w} a k a$ for the $2^{\text {nd }}$ person singular subject in example (4). ${ }^{7}$

\section{Chimila}

(4) $\widetilde{d} u \eta \eta-a-g^{w} a k a-t e$

walk-IPFV-2SG.SBJ-DECL

'You (sg.) walk.'

(Trillos Amaya 1997: 150)

In transitive constructions, the situation can be still more heterogeneous than in intransitive constructions. In Guatuso, for instance, a $1^{\text {st }}$ person agent ( $\left.\mathrm{ra}-\right)$ and a $2^{\text {nd }}$ person patient ( $\mathrm{ma}$-) are both indicated by prefixes (5).

Guatuso

(5) ma-ra-kuaye

2ABS-1ERG-see

'I see you (sg./pl.).'

(Constenla Umaña 1998: 73)

In Damana transitive constructions such as (6), $1^{\text {st }}$ person singular subject is expressed by a suffix $-k u$ and an unbound element $r a$ simultaneously, whereas $2^{\text {nd }}$ person singular object is indicated by $m a-$.

Damana

(6) $\boldsymbol{r a}$

ma-sak-u-ga

1SG 2SG.OBJ-search-1SG.SBJ-DECL

'I search you (sg.).'

(cf. Trillos Amaya 1999: 42)

\footnotetext{
${ }^{5}$ However, an unambiguous case of clitics marking verbal person is observed in Rama by Craig (n/d) (see Table 1): The person markers in question can be combined with plural marking enclitics which would make it difficult to interpret them as prefixes.

${ }^{6}$ Muisca $<\mathrm{i}->$, marking $1^{\text {st }}$ person singular subject has two allomorphs $<\mathrm{z}(\mathrm{e})->$ and $\varnothing$, the occurrence of which is phonologically conditioned.

${ }^{7}$ Trillos Amaya (1997: 123) gives - $u k a$ as the suffix indicating $2^{\text {nd }}$ person subject in Chimila. This element cannot be derived from Proto-Chibchan *ba or *bi ‘ $2^{\text {nd }}$ person’ (cf. Constenla Umaña 2012: 408).
} 
In Guaymí, both person of the agent and of the patient are marked by unbound forms, namely $m o$ for the $2^{\text {nd }}$ person and $t i$ for the $1^{\text {st }}$ person in (7).

Guaymí

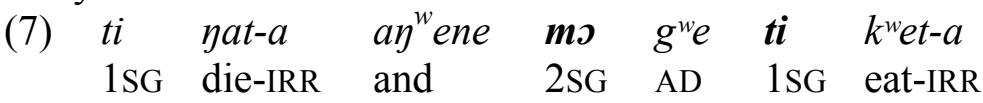

'And when I die, eat me.'

(Quesada Pacheco 2008: 125)

An overview of verbal person marking patterns in intransitive and transitive Chibchan constructions is given in Table 1. Languages are clustered together according to the subgrouping of Chibchan languages proposed by Constenla Umaña (2012: 415-7).

\begin{tabular}{|c|c|c|c|c|}
\hline Language & Subgroup & \multicolumn{2}{|c|}{$\begin{array}{l}\text { Patterns of verbal } \\
\text { person marking }\end{array}$} & Source \\
\hline Barí & $\begin{array}{l}\text { Southern } \\
\text { Magdalenic }\end{array}$ & $\mathrm{V}-\mathrm{s}$ & o-V-s & Own fieldwork data, Quesada (2004) \\
\hline Muisca & $\begin{array}{l}\text { Southern } \\
\text { Magdalenic }\end{array}$ & $\mathrm{s}-\mathrm{V}$ & $\mathrm{O}$ s-V; o-s-V & $\begin{array}{l}\text { Adelaar and Muysken (2004), González de Pérez } \\
\text { (1987) }\end{array}$ \\
\hline Tunebo & $\begin{array}{l}\text { Southern } \\
\text { Magdalenic }\end{array}$ & SV & SOV & Headland (1997) \\
\hline Chimila & $\begin{array}{l}\text { Northern } \\
\text { Magdalenic }\end{array}$ & V-s & V-o-s & Trillos Amaya (1997) \\
\hline Kogi & $\begin{array}{l}\text { Northern } \\
\text { Magdalenic }\end{array}$ & V-s, s-V & $o-\mathrm{V}-\mathrm{s} ; \mathrm{s}-\mathrm{o}-\mathrm{V}$ & Olaya Perdomo (2000), Ortíz Ricaurte (2000) \\
\hline Guaymí & Eastern Isthmic & SV & SOV & Quesada Pacheco (2008) \\
\hline Kuna & Eastern Isthmic & SV & SOV & Holmer (1947) \\
\hline Cabécar & Western Isthmic & SV & SOV & Margery Peña (1989) \\
\hline Teribe/Térraba & Western Isthmic & SV & SOV; O V-s & Quesada (2000a), Constenla Umaña (2007) \\
\hline Guatuso & Votic & $\mathrm{s}-\mathrm{V}$ & $\mathrm{o}-\mathrm{a}-\mathrm{V}$ & Constenla Umaña (1998) \\
\hline Rama & Votic & $\mathrm{SV} ; \mathrm{s}=\mathrm{V}$ & $\mathrm{SOV} ; \mathrm{O} \mathrm{s}=\mathrm{V}$ & Craig (n/d) \\
\hline Paya & Paya & V-s & $0-\mathrm{V}-\mathrm{s}$ & Holt (1999) \\
\hline
\end{tabular}

Table 1. Some Chibchan patterns of verbal person marking in intransitive and transitive constructions ${ }^{8}$

The relationship between the patterns described in Table 1 and the subgrouping of Chibchan languages as proposed by Constenla Umaña (2012: 415-7) is not always straightforward. An example of a mismatch between Chibchan subgrouping and patterns of verbal person marking is illustrated by Chimila and Kogi. Both languages are grouped within the Northern Magdalenic languages by Constenla Umaña (2012: 413-4; 416-7), on the basis of phonological and morphological evidence and shared isoglosses.

\footnotetext{
${ }^{8}$ Capitals indicate unbound person markers, hyphens indicate affixes and equal signs indicate clitics. The affixal status of verbal person markers in Kogi and Paya is discussed in section 2. Note also that for Cabécar, Guaymí and Tunebo, an ergative-absolutive alignment has been proposed by the respective authors of the descriptions I draw upon for these languages. Nonetheless, only Guatuso is presented here as an ergative language since it is the only case of an ergative-absolutive alignment reflected in the verb. In Cabécar, Guaymí and Tunebo, the ergative marking element may also be interpreted, from a synchronic point of view, as an agent disambiguator.
} 
However, not only do Chimila and Kogi have different etyma underlying for instance markers of the $2^{\text {nd }}$ person singular subject (see (4) and (11)); the patterns of verbal person marking are also different: whereas Chimila only uses suffixes (V-s; V-o-s), Kogi makes use of prefixes $(\mathrm{s}-\mathrm{V}$; s-o-V), suffixes $(\mathrm{V}-\mathrm{s})$ or a mix of both $(\mathrm{o}-\mathrm{V}-\mathrm{s})$, according to the authors of the respective language descriptions (see Table 1). A similar example is provided by Barí, Tunebo and Muisca. These three languages are grouped together in Southern Magdalenic by Constenla Umaña (2012: 413-4; 416-7). Nonetheless, their strategies of verbal person marking are different, Tunebo using unbound forms (SV; SOV), Muisca making use of both unbound forms and prefixes (s-V; O s-V; o-s-V), and Barí indicating verbal person by suffixes (V-s) and a mix of both prefixes and suffixes $(\mathrm{o}-\mathrm{V}-\mathrm{s})$. In part, such heterogeneity seems to be the result of relatively recent change since it is attested within single subgroups. The existence of two patterns such as Muisca o-s-V and Barí o-V-s in Southern Magdalenic strongly suggests the grammaticalization of unbound forms at a certain moment, in at least one of the two languages. Unbound verbal person markers are generally less constrained and fixed in order than are bound verbal person markers (Bickel \& Nichols 2005). They may therefore grammaticalize in different positions. Instead, affixed elements should yield bound verbal person markers in different slots less easily. Therefore, it seems that in some cases at least, bound verbal person markers in Chibchan are derived from unbound elements (cf. also Himmelmann 2014). This interpretation is roughly in line with Ostler (2000) and Constenla Umaña (2012: 408) who argue - on different grounds, however - that Chibchan person marking prefixes are derived from originally unbound forms. ${ }^{9}$ For the sake of completeness, a brief overview of some Chibchan forms marking verbal person in intransitive constructions is given in Table 2.

\begin{tabular}{|c|c|c|c|c|c|c|c|}
\hline & Tunebo & Kogi & Chimila & Kuna & Boruca & Cabécar & Guatuso $^{10}$ \\
\hline $1^{\text {st }} \mathrm{sg}$. & asa & $-k u$ & $-n$ & $a n$ & $\dot{a} t$ & $\widehat{d} z i s$ & $n a-$ \\
\hline $1^{\mathrm{st}} \mathrm{pl}$. & $i s a$ & $k a-$ & $\begin{array}{l}\text { - } \eta k r e \text { (dual)/ } \\
\text { - } \eta k r e-m b r e \text { (plural) }\end{array}$ & an-mala & $d i ?$ & $\begin{array}{l}\text { sé (incl.) } \\
\text { sá (excl.) }\end{array}$ & $n a-$ \\
\hline $2^{\text {nd }} \mathrm{sg}$ & bara & $b a-$ & $-u k a$ & pe & $b a ́$ & $b a ́$ & $m i-\sim m a-$ \\
\hline $2^{\text {nd }} \mathrm{pl}$. & $b a:$ & $b i-$ & $\begin{array}{l}\text {-uka-ra (dual)/ } \\
-u k a-r a-m b r e \text { (plural) }\end{array}$ & pe-mala & $b i ?$ & bás & $m i-\sim m a-$ \\
\hline
\end{tabular}

Table 2. Some Chibchan verbal person markers used in intransitive constructions

[References for language data: Tunebo (Headland 1997); Kogi (Olaya Perdomo 2000); Chimila (Trillos Amaya 1997); Kuna (Holmer 1947); Boruca (Quesada Pacheco \& Rojas Chaves 1999); Cabécar (Margery Peña 1989); Guatuso (Constenla Umaña 1998)]

\section{Diachronic Developments}

The preceding section has briefly illustrated the different morphosyntactic properties of verbal person marking in Chibchan; in some cases, relatively recent processes of grammaticalization can be inferred from bound person markers affixed in different positions in the languages of one subgroup - compare, for instance, the case of Barí and

\footnotetext{
9 Ostler (2000) refers to person marking prefixes in Ika, Kogi, Damana and Muisca. According to Constenla Umaña (2012: 408), "[i]n view of the absence of person prefixes in several languages [...], the best hypothesis [...] is that Proto-Chibchan had an optional alternation between independent and proclitic forms of the personal pronouns [...], and that the proclitic forms gave rise to the prefixes".

${ }^{10}$ In Guatuso, plural person (subject or agent) may be indicated by additional unbound pronouns preceding the verb. (cf. Constenla Umaña 1998: 73)
} 
Muisca. However, the derivation of unbound forms from bound forms combining with a pronominal base also seems to have occurred in Chibchan. The present section takes a closer look at these developments.

In the following I will argue that preverbal person markers are derived from originally unbound forms in Paya, spoken in northeastern Honduras, as well as in Kogi, a Chibchan language of the Sierra Nevada de Santa Marta (Colombia). In Paya, the element indicating object person precedes the verb root and has been interpreted as a prefix by Holt (1999) (8).

Paya
(8) pi-wà:-k-r-í?
2OBJ-carry-PNCT-PL-PST
'They carried you (sg.).'
(Holt 1999: 27)

The $2^{\text {nd }}$ person object is expressed, in (8), by an element pi- (the unbound form indicating $2^{\text {nd }}$ person singular is pà: (Holt 1999: 40)). In some constructions however, it turns out that this $2^{\text {nd }}$ person object marker is followed by an element $r$ - (9).

Paya

(9) pi-r-tamih-pã

2.OBJ-OBJ-pay-1sG.SBJ.FUT

'I will pay you (sg.).'

(Holt 1999: 70)

A construction such as (9) with the object person marker followed by an element $r$ makes it difficult to reconstruct Paya $p i$ - as an originally bound person marker for the following reason: A formally identical element $-r$, also labelled an 'objective' marker by Holt (1999: 34), can be attached to nouns (10).

Paya

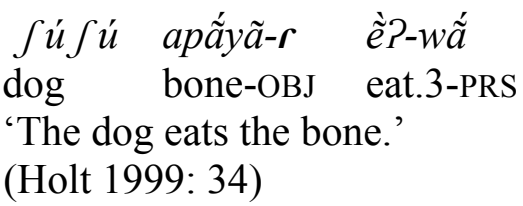

Thus, since an element $r$ - follows $p i$ - in the verbal complex, an interpretation of $p i$ - as a prefix might appear debatable for present-day Paya. Alternatively, we would be dealing here with a clitic element. In any case, it seems impossible to argue that this person marker derives from a bound prefix. A similar case is attested in Kogi. In this language, person of the direct object is indicated by an element which has been interpreted as a prefix by different authors (11). 
Kogi

(11) ma-la-'bei-a-li

2SG.SBJ-1 SG.OBJ-Say-DECL?-FUT ${ }^{11}$

'You will talk with me.'

(Ortiz Ricaurte 2000: 775)

The first person object is indicated, in (11), by an element $l a-.{ }^{12}$ In ditransitive or dative experiencer constructions, however, this object person marker is followed by an element $k-(12)$.

Kogi

(12)

$\begin{array}{ll}\text { bi'giza } & \boldsymbol{n a} \text { - } \boldsymbol{k} \text {-'luni } \\ \text { pineapple } & \text { 1SG.OBJ-DAT-want }\end{array}$

'I want a pineapple.'

(Ortiz Ricaurte 2000: 774, cited in Adelaar \& Muysken 2004: 72)

The element $k$ - in (12) must probably be interpreted as a separate affix rather than as part of an indirect object person marking prefix *nak-. An element $-k$ is used, in the same language, as a goal marking case suffix (13).

Kogi

(13)

$\begin{array}{lll}m i-h u-k & n a k & n i-g u-' k u \\ \text { 2SG.POSS-house-DAT } & \text { come } & \text { DECL-do-1SG.SBJ } \\ \text { 'I came to your house.' } & \\ \text { (Ortiz Ricaurte 2000: 772) } & \end{array}$

Thus, as in Paya, it is not necessarily easy to interpret the preverbal element marking object person in Kogi as a prefix since it is followed by a an element $k$ - in (12). This would be sufficient to argue that Kogi subject person marking elements such as ma-, indicating $2^{\text {nd }}$ person subject in (11), are not prefixes, either. From a diachronic perspective, no room seems to be left for an origin of these Kogi person markers in bound prefixes.

In Térraba, a Chibchan language from western Panama and eastern Costa Rica, a different development seems to have taken place: there are unbound person markers which are built on bound elements that are attached to a pronominal base. Object person in Térraba is indicated by one of two different unbound elements (14)-(15), the choice of which depends on topicality (cf. section 3 on the pragmatic differences between these constructions).

Térraba

(14) $t^{\text {ha }} \boldsymbol{a} \quad k u^{\prime}-a$

1SG hear-3

'S/he hears me.'

(Constenla Umaña 2007: 77)

\footnotetext{
${ }^{11}$ Ortiz Ricaurte (2000: 775) interprets - $l i$ as a progressive marker in this context. Olaya Perdomo (2000: 782-3) interprets $-l i$ as indicating future tense.

${ }^{12}$ Note the phonologically determined alternation between $n a$ - and $l a$ - in (11) and (12).
} 
(15) (e) bo-r kúk

3SG SF-1SG hear

'(S)he hears me.'

(Constenla Umaña 2007: 77)

Constenla Umaña (2007: 76-7) interprets bo-r in (15) as a generic pronominal root, bo-, combining with an element $-r$, which is also attested as a verbal suffix marking subject person in transitive constructions. There is a whole paradigm of these derived unbound person markers which are also used as possessive determiners. The element $b o$ is etymologically opaque and does not occur in unbound form, that is, on its own, in Teribe/Térraba. Such a development, namely, the formation of unbound person markers from bound person markers combining with generic pronominal roots would be less frequent than the derivation of bound person markers from unbound person markers, cross-linguistically speaking (cf. Siewierska 2004: 254).

The evidence listed in examples (8)-(13) suggests that both in Paya and Kogi, the preverbal elements marking object person (and subject person, in Kogi) can only be reconstructed as unbound elements for the respective pre-languages, but not as prefixes. If, from a synchronic perspective, we maintain an interpretation of these elements as bound prefixes, we would be dealing here with an accomplished development from unbound to bound verbal person markers. In fact, there are also reasons to argue that the elements in question are proclitics. We might thus be witnessing an ongoing process of grammaticalization here. Instead, as attested in (14) and (15), it seems that in Teribe/Térraba, unbound person markers are built on dependent person markers and generic pronominal roots. Thus, from a diachronic point of view, the situation of analytic and synthetic strategies of verbal person marking appears to be rather dynamic in some Chibchan languages.

\section{Synchronic Alternations}

Some Chibchan languages display alternating strategies for verbal person marking: verbal person can be indicated by either bound or unbound forms in Muisca, Teribe/Térraba, and Rama. In order to give an account on the morphosyntactic properties of Chibchan verbal person marking from a synchronic perspective, these cases will be discussed in the present section. As will be argued, the choice of either bound or unbound morphemes seems to be linked with hierarchies that are based on cognitive issues.

In both Teribe/Térraba and Rama, information structure in the specific discourse situation determines the choice of a bound or unbound element for verbal person marking (see also Quesada 2000b). In Teribe, person of the given subject (topic) is indicated by a suffix in transitive constructions, when the object person is introduced as a new participant (Quesada 2000a: 108) (16).

Teribe

(16) pa fpo-ro-r

2SG hit-PFV-lSG.SBJ

'I hit you.'

(Quesada 2000a: 108) 
Otherwise, both the person of the subject and the object are indicated by unbound elements (17).

Teribe

$\begin{array}{lll}\text { (17) } & \text { pa } \quad \text { bo-r } & \text { kimt } \\ \text { 2SG } & \text { SF-1SG } & \text { help } \\ \text { 'You help me.' } \\ \text { (Quesada 2000a: } 109)\end{array}$

For Rama, a Chibchan language of southeast Nicaragua, Craig (n/d: 104-5) describes a very similar phenomenon for verbal person marking in intransitive constructions. In this language, person of an already introduced subject, that is, the topic, is indicated by a clitic form (19), and not by an independent pronoun (18) (both examples are part of a narrative where (19) follows (18)).

Rama

(18) niy taim nah juwa tiy-nana:k-i

DEM time $1 \mathrm{SG}$ old become-toward-PRS

'Now I am getting old.'

(Craig n/d: 105)

$\begin{array}{lll}\text { tirskam } & \boldsymbol{n}=\text { a:kar- } a & \text { taim-ki } \\ \text { child } & 1 \mathrm{SG} . \mathrm{SBJ}=\text { be-TNS }^{13} & \text { time-L }\end{array}$

'At the time I was a child.'

(Craig n/d: 105)

A similar, albeit more complex case is attested in Muisca, an extinct Chibchan language formerly spoken in the Boyacá and Cundinamarca high plains of Colombia. Adelaar and Muysken (2004: 97) identify two sets of bound person marking elements in this language (Table 3$){ }^{14}$

\begin{tabular}{llll}
\hline Muisca & Set 1 & Set 2 & Unbound form \\
\hline $1^{\text {st }}$ person singular & $<\mathrm{z}(\mathrm{e})->$; $<\mathrm{i}->$; $\varnothing-$ & $<$ ch(a)- & $<$ hycha $>$ \\
$1^{\text {st }}$ person plural & $<$ chi- $>$ & $<$ chi- $>$ & $<$ chie $>$ \\
$2^{\text {nd }}$ person singular & $<$ vm- $>$ & $<$ m(a) $->$ & $<$ mue $>\sim<$ muy $>$ \\
$2^{\text {nd }}$ person plural & $<$ mi- $>$ & $<$ mi- $>$ & $<$ mie $>$ \\
$3^{\text {rd }}$ person & $<$ a- $>$ & $\varnothing-$ & $<$ sisy $>,<$ ysy $>,<$ asy $>$
\end{tabular}

Table 3. Person marking in Muisca (cf. González de Pérez 1987: 74-5, 81-2, 87; Adelaar \& Muysken 2004: 97)

These two sets cannot easily be labeled as 'subject set' and 'object set'. While Set 1 does not refer to object person, Set 2 and the unbound forms can refer to subject or object

\footnotetext{
${ }^{13}$ Craig (n/d: 147) interprets Rama - $a$ as marking "neutral tense" and states that it "is very rarely used and its meaning is difficult to define".

${ }^{14}$ Alternative interpretations of person markers in Muisca can be found in Ostler $(1994 ; 2000)$.
} 
person, depending on the context. ${ }^{15}$ In the indicative mood, Set 1 is used to mark the subject in intransitive constructions (20).

Muisca

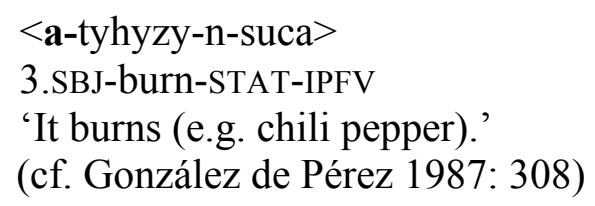

In transitive constructions, Set 1 prefixes can indicate person of the subject, too, as for instance in (21) and (22).

Muisca

$$
\begin{aligned}
& <\text { mue } \quad \text { zhy-guity-fuca }> \\
& \text { 2SG 1SG.SBJ-beat-IPFV } \\
& \text { 'I am beating you.' } \\
& \text { (Lugo 1619: 96r) }
\end{aligned}
$$

(22) <hycha vm-guity-fucà>

1SG 2SG.SBJ-beat-IPFV

'You are beating me.'

(Lugo 1619: 96v)

Thus, only subject person is indicated by bound forms in examples (20) to (22), object person in (21) and (22) is indicated by unbound forms. In these examples, bound and unbound person markers are distributed according to the syntactic functions of subject and object, that is, according to a "hierarchy of argument prominence" (Siewierska 2004: 43) with the subject ranking higher than the object. The person referred to by the higher ranking syntactic element (that is, the subject) is indicated by a bound form, whereas an unbound form indicates the hierarchically lower ranking object person. From a cross-linguistic perspective, this distribution of bound subject markers and unbound object markers is the most frequently attested (Siewierska 2004: 43).

As a general rule, bound person markers tend to encode less information than unbound person markers (Siewierska 2004: 46). This would explain why, across different languages, bound person markers tend to encode person of "highly accessible referents" (Siewierska 2004: 46; 175, cf. also Ariel 1990: 77-8), that is, rather subject than object person. Subject person should be cognitively more accessible than object person since it tends to rank higher on other hierarchies, too, such as animacy or topicality hierarchies (cf. Givón 1983: 20-3; de Swart et al. 2007). Similar considerations apparently also hold for the situation in Muisca, illustrated in examples (20) to (22).

\footnotetext{
15 The differences between Set 1 and Set 2 are discussed in detail by Adelaar and Muysken (2004). According to these authors, participles and passive verbs take Set 2 to refer to the subject (or patient, in passive constructions) (see Adelaar \& Muysken 2004: 96-8). With nouns, Set 1 prefixes mark person of the possessor, whereas in predicative constructions (non-verbal predicates), person of the subject is indicated by Set 2 prefixes, according to Adelaar and Muysken (2004: 98).
} 
Nonetheless, o-s-V patterns with prefixes marking object person are attested in Muisca as well (23). ${ }^{16}$

Muisca

(23) $<$ Pedro-z

mi-a-guyt-ua>

Pedro-? 2PL.OBJ-3.SBJ-beat.PST-Q

'Did Pedro beat you (pl.)?'

(González de Pérez 1987: 143, cited in Adelaar \& Muysken 2004: 98)

This alternation between $\mathrm{O} \mathrm{s-V} \mathrm{((21)-(22))} \mathrm{and} \mathrm{o-s-V} \mathrm{patterns} \mathrm{(23)} \mathrm{in} \mathrm{Muisca} \mathrm{needs}$ further discussion. It is clear that a subject/object hierarchy is not the only one which may underlie patterns of verbal person marking. Languages can have person hierarchies implying, for instance, that speech act participants (SAP, i.e., $1^{\text {st }}$ and $2^{\text {nd }}$ person) rank higher than non-SAPs $\left(3^{\text {rd }}\right.$ person) in terms of saliency or cognitive accessibility (cf. Ariel 1990; Zúñiga 2006: 20-2). This latter phenomenon is exactly what can be observed in Muisca as well. In terms of a hierarchy based on an SAP/non-SAP distinction the two participants involved in each (21) and (22) concur. They only differ with respect to their subject/object status which therefore appears to determine their affixal realization in this context. In (23) however, the situation is different since SAP (ranking high in person hierarchy) interacts with a non-SAP (ranking low in person hierarchy).

In this context, it is important to note the following observation of Siewierska (2004: 43): Cross-linguistically, the use of bound elements indicating person of the object (that is, a low ranking entity in terms of cognitive accessibility hierarchy) entails the use of bound markers for the subject person. Transferring this rule to a hierarchy based on an SAP/non-SAP distinction, this would imply the following: in constructions where person of the non-SAP (ranking low in person hierarchy) is indicated by a bound element (because it is the subject), a $1^{\text {st }}$ or $2^{\text {nd }}$ person involved (ranking higher in person hierarchy) should be indicated by a bound element as well, irrespective of its status as an object. And indeed, this is exactly what can be observed in Muisca ((23), repeated here as (24); and (25)-(26)).

Muisca
$<$ Pedro-Z
mi-a-guyt-ua>
Pedro-? 2PL.OBJ-3.SBJ-beat.PST-Q

'Did Pedro beat you (pl.)?'

(González de Pérez 1987: 143, cited in Adelaar \& Muysken 2004: 98)

(25) $<$ Pedro ch-a-guity $>$

Pedro 1SG.OBJ-3.SBJ-beat.PST

'Pedro beat me.'

(González de Pérez 1987: 143, cited in Adelaar \& Muysken 2004: 98)

\footnotetext{
${ }^{16}$ The analysis of $<$ mi-a- $>$ in (23) as two separate morphemes is based on the interpretation of Adelaar and Muysken (2004: 97). González de Pérez (1987: 143) explicitly states that, together with verbs, a construction such as (23) implies a $3^{\text {rd }}$ person subject ("el chia y mia no se juntan más q[ue] con el v[er]bo de tersera persona").
} 
Whether prefixes marking hierarchically low ranking person literally determine the hierarchically higher ranking person to be indicated by a bound marker too, or whether a hitherto unknown factor underlies this conditioned correlation is difficult to assess. But on the descriptive level it seems that two hierarchies are inherent in Muisca morphosyntax, one reflecting a subject/object distinction, the other a SAP/non-SAP distinction. Considerations of cognitive accessibility may ultimately underlie both of them. The two hierarchies identified for Muisca are, in turn, hierarchically organized as well. Subject person is indicated by a bound element in constructions such as (20) to (26). Object person is only indicated by a bound element in case it ranks higher than subject person in the Muisca person hierarchy, which makes a difference between SAP and non-SAP. In this case, however, the non-SAP is also indicated by a bound element. Since the hierarchies underlying verbal person marking in Muisca are hierarchically organized themselves, they will be labeled 'nested hierarchies' here (see Table 4).

\begin{tabular}{lll}
\hline Hierarchy & high & low \\
\hline \multirow{2}{*}{ high } & Hierarchy 1 & Hierarchy 2 \\
\cline { 2 - 3 } low & subject & speech act participant \\
\hline
\end{tabular}

Table 4. Nested hierarchies in Muisca

The nested hierarchies attested in Muisca verbal person marking seem to be unique within Chibchan. The examples from Muisca, Rama and Teribe discussed above suggest that in individual languages, choice of bound or unbound verbal person markers correlates with cognitive accessibility: the relevant hierarchy reflects topicality considerations in Teribe/Térraba and Rama, and syntactic roles and speech act participation in Muisca.

\section{Conclusions}

The present paper has presented and discussed several aspects of synthetic and analytic verbal person marking strategies in Chibchan. First, it has been argued that synthetic verbal person marking in Chibchan languages is not necessarily the result of deep-time retention (section 1). In fact, the grammaticalization process of independent person markers into more dependent person markers can be traced in Kogi and Paya. A different development, namely the use of bound person markers to derive a new set of unbound person markers, seems to be attested in Teribe/Térraba (section 2). This is in line with Wichmann's and Holman's (2009: 22; 24) observation that person marking and inflectional synthesis of the verb are "very unstable" features, at least among the languages treated in the World Atlas of Language Structure (WALS) (Haspelmath et al. 
2005) ${ }^{17}$ From a synchronic perspective, it seems that in individual Chibchan languages, such as in Rama, Teribe/Térraba and Muisca, synthetic verbal person marking correlates with cognitive accessibility: bound elements are used to indicate person of a salient referent. Saliency seems to reflect topic/focus considerations in Teribe and Rama. In Muisca it instead seems to correlate with two different dimensions, namely speech-act participation and syntactic role. The interaction of both dimensions in Muisca yields nested hierarchies (section 3).

In future studies, it would be worthwhile to trace the role of language contact as affecting the morphosyntactic properties of verbal person marking of different Chibchan languages. Based on cross-linguistic evidence, van Gijn (this volume) states that language contact often leads to a simplification, in terms of morphological complexity. As a matter of fact, Adelaar (2002) proposes the possibility of an influence of Chocoan languages, triggering analytic person marking strategies in Kuna. ${ }^{18} \mathrm{~A}$ multilingual setting may also account for the analytic person marking strategies in Tunebo (see Table 1) (cf. Cassani 1741, cited in Restrepo 1895: 21). Whether or not the relatively complex morphosyntactic properties of verbal person marking in other eastern Chibchan languages have been triggered by language contact would be a matter of further investigation.

\footnotetext{
${ }^{17}$ Note that the stability of inflectional synthesis of the verb and verbal person marking also depends on the number of categories which are encoded by bound morphology (Wichmann \& Holmann 2009).

${ }^{18}$ At present, verbal person is mostly indicated by unbound elements in Chocoan languages.
} 


\section{References}

Adelaar, Willem F. H. 2002. Solving the South American puzzle: a reappraisal of basic lexicon comparison in genealogical linguistics. Paper presented at The Language Blueprint Workshop, NIAS, Wassenaar, 11-13 January 2002. 2007 Preface. In: Quesada, Juan Diego. The Chibchan Languages, pp. 11-12. Cartago, Costa Rica: Editorial Tecnológica de Costa Rica. with the collaboration of Pieter C. Muysken. 2004. The Languages of the Andes. Cambridge: Cambridge University Press.

Ariel, Mira. 1990. Accessing Noun-Phrase Antecedents. London: Routledge.

Bickel, Balthasar and Johanna Nichols. 2005. Inflectional Synthesis of the Verb.

The World Atlas of Language Structures, Martin Haspelmath, Matthew S. Dryer, David Gil, and Bernard Comrie (eds.), pp. 94-7. Oxford: Oxford University Press.

Cassani, Joseph. 1741. Historia de la provincia de la Compañia de Jesus, del Nuevo Reyno de Granada en la America, Descripción, y relación exacta de sus gloriosas missiones en el reyno, llanos, meta, y rio orinoco, almas, y terreno, que han conquistado sus missioneros para Dios, aumento de la christiandad, y extension de los dominios de su mag. catholica. Madrid: Manuel Fernandez.

Constenla Umaña, Adolfo. 1993. La familia chibcha. Estado actual de la clasificación de las lenguas indígenas de Colombia. Ponencias presentadas en el seminario-taller realizado en el Instituto Caro y Cuervo (Febrero 10, 11, y 12 de 1988), M. L. Rodríguez de Montes (ed.), pp. 75-125. Santafé de Bogotá: Instituto Caro y Cuervo. 1998. Gramática de la lengua guatusa. Heredia, Costa Rica: Euna.

2007. La lengua de Térraba. San José, Costa Rica: Editorial Universidad de Costa Rica.

2012. Chibchan languages. The Indigenous Languages of South America. A Comprehensive Guide, Lyle Campbell and Verónica Grondona (eds.), pp. 391439. (The Indigenous Languages of South America, WOL no. 2.) Berlin/Boston: De Gruyter Mouton.

Craig, Colette. n/d. A Grammar of Rama. Université de Lyon. Report to National Science Foundation, BNS 8511156. Manuscript.

de Swart, Peter, Monique Lamers, and Sander Lestrade. 2007. Animacy, argument structure, and argument encoding. Lingua 118 (2):131-40.

Gijn, Rik van. This volume. The stability of complex verbal morphology.

Gijn, Rik van, and Fernando Zúñiga. 2014. Word and the Americanist perspective. Morphology 24 (3): 135-160.

Givón, Talmy 1983. Topic continuity in discourse: An introduction. Topic Continuity in Discourse: A quantitative cross-language study, Talmy Givón (ed.), pp. 1-41. Amsterdam: John Benjamins.

González de Pérez, María Stella. 1987. Diccionario y gramática chibcha. Manuscrito anónimo de la Biblioteca Nacional de Colombia. Santafé de Bogotá: Instituto Caro y Cuervo.

Haspelmath, Martin. 2011. The indeterminacy of word segmentation and the nature of morphology and syntax. Folia Linguistica 45 (1): 31-80. 
, Dryer, Matthew, Gil, David, and Bernard Comrie (eds.) 2005. The World Atlas of Language Structures. (Book with interactive CD-ROM) Oxford: Oxford University Press.

Headland, Edna R. 1997. Diccionario Bilingüe uw cuwa (tunebo)-español, español-uw cuwa (tunebo) con una grámatica uw cuwa (tuneba). Santafé de Bogotá: Asociación Instituto Lingüístico de Verano.

Himmelmann, Nikolaus P. 2014. Asymmetries in the prosodic phrasing of function words: another look at the suffixing preference. Language 90 (4): 927-60.

Holmer, Nils M. 1947. Critical and Comparative Grammar of the Cuna Language. (Etnologiska Studier, vol. 14.) Gothenburg: Etnografiska Museet.

Holt, Dennis. 1999. Pech (Paya). (Languages of the World/Materials, 366.) Munich: Lincom Europa.

Lugo, Bernardo de. 1619. Gramática en la lengua general del Nuevo Reyno, llamada Mosca. Madrid: Bernardino de Guzmán.

Margery Peña, Enrique. 1989. Diccionario cabécar-español, español-cabécar. San José, Costa Rica: Editorial de la Universidad de Costa Rica.

Olaya Perdomo, Noel. 2000. Descripción preliminary del sistema verbal de la lengua kogui (o kawgi), Lenguas indígenas de Colombia, Una visión descriptiva, María Stella González de Pérez and María Luisa Rodríguez de Montes (eds.), pp. 481-7. Santafé de Bogotá: Instituto Caro y Cuervo.

Ortiz Ricaurte, Carolina. 2000. Fonología y morfosintaxis nominal del Kogui. Lenguas indígenas de Colombia, Una visión descriptiva, María Stella González de Pérez and María Luisa Rodríguez de Montes (eds.), pp. 757-80. Santafé de Bogotá: Instituto Caro y Cuervo.

Ostler, Nicholas. 1994. Verb inflexion in Muisca and the Chibchan languages of Colombia. Paper delivered at the 48th International Congress of Americanists, Stockholm /Uppsala, Sweden: 4-9 July 1994.

2000. Development of transitivity in the Chibchan languages of Colombia. Historical Linguistics 1995: Selected Papers from the 12th International Conference of Historical Linguistics, Manchester, August 1995, John Charles Smith and Delia Bentley (eds.)., pp. 279-293. (Volume 1, General Issues and Non-Germanic Languages.) Amsterdam/Philadelphia: John Benjamins.

Quesada, Juan Diego. 2000a. A Grammar of Teribe. (Lincom Studies in Native American Linguistics, 26.) Munich: Lincom Europa.

2000b. Word order, participant encoding, and the alleged ergativity in Teribe. International Journal of American Linguistics, 66 (1): 98-124.

2004. The Barí language of Venezuela: a glimpse at the Chibchan periphery. Sprachtypologie und Universalienforschung 57 (4): 362-376.

2007. The Chibchan Languages. Cartago, Costa Rica: Editorial Tecnológica de Costa Rica.

Quesada Pacheco, Miguel Ángel. 2008. Gramática de la lengua guaymí (ngäbe). (Languages of the World/Materials, 272.) Munich: Lincom. , and Carmen Rojs Chaves. 1999. Diccionario Boruca-Español, Español-Boruca. San José, Costa Rica: Editorial de la Universidad de Costa Rica.

Restrepo, Vicente. 1895. Los chibchas antes de la conquista española. Santafé de Bogotá: Imprenta de la luz.

Siewierska, Anna. 2004. Person. Cambridge: Cambridge University Press. 
Trillos Amaya, María. 1997. Categorías gramaticales del ette taara - lengua de los chimilas. (Lenguas aborígenes de Colombia, Descripciones 10.) Santafé de Bogotá: Universidad de los Andes. . 1999. Damana. (Languages of the World/Materials, 207). Munich: Lincom Europa.

Wichmann, Søren and Eric W. Holman. Temporal Stability of Linguistic Typological Features. (Lincom Studies in Theoretical Linguistics, 42.) Munich: Lincom.

Zúñiga, Fernando. 2006. Deixis and Alignment. Inverse systems in indigenous languages of the Americas. Amsterdam: John Benjamins. 